receives applications from private individuals wishing to build their own hydroelectric plants, monitors progress towards energy sufficiency, tells oil refineries how to operate, stockpiles strategic oil reserves and, partly as the residual legatee of the operational part of the old Atomic Energy Commission but also because of the wish-fulfillment of successive congresses and presidents, administers a research budget of $\$ 2,000$ million. The danger is that in unscrambling this omelette, the White House will sacrifice on ideological grounds those parts of the department's work that cannot be moved about like the pieces in a board game.

The research budget is the most vulnerable. Most of the administrative functions specified by legislation could probably be transferred, without ambiguity, to the Departments of Commerce or of the Interior in such a way that nobody would know six months later that there had been a change. The department's research will need gentler handling, even though the case for dismemberment is stronger. For it has always been anomalous, the result of an historical accident, that first the Atomic Energy Commission and now the Department of Energy should be responsible for essentially academic research in highenergy physics. The natural home for this function is the National Science Foundation; for is not high-energy physics part of basic research? This proposal will not be welcome to the high-energy physics community, by now well used to the department's avuncular ways. But they are likely to be safer with the foundation than with the other agencies to which they might be shuttled. For them, there is either the frying-pan or the fire.

The other components of the department's research budget are in for a rougher ride. Already the Administration has made it plain that the ambitious Carter plan for research and development (by publicly supported demonstration) in solar energy will be drastically cut back, on the grounds that those parts of programmes likely to yield short-term benefits should be able to stand on their own feet. Basic research in, say, photovoltaic processes is unlikely to grind to a halt - the service departments will probably take up the slack. But environmentalists will be up in arms. With this precedent for solar energy, however, the White House planners will have an awkward decision to make on nuclear energy. It will be easy to suggest that the weapons laboratories at Los Alamos and Livermore should go to the Department of Defense, but should there be public support of any kind for a technology as well advanced as the civil application of nuclear energy? Both the ideologues of small government and the environmentalists will make hay of that.

The difficulties the Administration will encounter on such matters are self-inflicted. On solar energy, the Administration would have been on sure ground if it had said, earlier in the year, that $\mathrm{Mr}$ Carter's legacy of solar energy research was too ambitious, too unrealistic and too costly, and that substantial trimming would be necessary. Instead, the Administration seems to have put its tongue in its cheek (and hoped to head off a fight with Congress as a result) by saying that the time has come when industry should take up the slack. This is disingenuous. Even if the assumption were true, there would be a case for continued government investment in the basic research and technology of, say, direct electricity generation from sunlight. The same is true of the civil nuclear programme. Does the United States want to be stuck for years to come with those systems that manufacturers are able now to offer? Paradoxically, and inconsistently, the Administration seems to have accepted this argument for the programme for converting coal into synthetic fuels, and has agreed that its demonstration programme should continue.

The moral, for the disbandment of the Department of Energy, is that the Administration should be careful that it picks up the essential pieces if and when the department is closed. The proposals to disband the Department of Education will be more contentious but will raise fewer substantial issues. Given the principle that education at all levels is the responsibility of private institutions, it is outwardly consistent that the federal government should withdraw. But is it proper that the Administration should now pretend to wash its hands of responsibility for education? And does it intend, in the process, to transfer responsibility for the truncated programme of student loans to the private banking sector? Will it give up the fight on engineering education, now hamstrung by the competition from industry for potential academics? In the old days of the Department of Health, Education and Welfare, such issues could be followed up provided there was a strong man in charge of the Office of Education. Now there is no natural home for such an agency. The Administration may find it necessary to invent one.

\section{Monuments for whom?}

The Department of the Environment is well on the way to making a muddle of its policy on British ancient monuments and on Stonehenge in particular. Quite properly, the department is anxious that the monuments should not deteriorate still further as a consequence of their popularity with summer tourists. For if the mountain paths in highland Britain are in danger of being eroded by the hobnailed boots of those who must now in the summer holidays queue for a place in the line of those clambering up the popular spots, the threat to more accessible places such as Stonehenge is evidently great. The trouble is that the department's policy appears to be based on the assumption that all visitors to these places are potentially vandals. The result is that even access by archaeologists to the monument at Stonehenge is being controlled as rigorously as if these learned people were likely to paint their names with spray-cans on the standing stones once the custodians' backs were turned. Briefly, parties of archaeologists must apply in advance to the Department usually allowed to visit it for an hour in the early morning on Tuesdays only, before the public is admitted to the site at 9 a.m. (but all day during the winter).

By any standards, this policy smacks too much of bumbledom. The chances that serious academic people will be able to carry out serious work during such brief intervals are negligible. The department may fear that members of the public (who are now kept some distance from the site by a ring fence) might be maddened beyond restraint by the sight of academics given closer access and even the opportunity to turn a spade, but that is a poor excuse. So too is the ready calculation that more access by archaeologists would mean a larger wages bill to cover the cost of supervision that is not, in all the circumstances, strictly necessary. For serious archaeologists, the present restrictions are all the more galling because of the department's apparently willing agreement that members of the whimsical order of druids should be allowed each summer solstice to conduct a ceremony on the site in a laughable attempt to perpetuate the ceremonies supposed to have been enacted at Stonehenge some years ago. And while nobody disputes that the site at Stonehenge must somehow be protected, few hearts leap up at the sight of the car park, the public lavatories and the money-making snack bar with which the department has graced the sight - admittedly below eye-level.

In the circumstances, the most urgent need is for a coherent policy by means of which the archaeological and public interests in important sites can cheerfully coexist. The department does indeed support a Commission on Ancient Monuments, to which advisory committees of archaeologists are entitled to make their case. What seems most of all to be lacking is imagination. There can be few circumstances in which members of the general public would not be enlivened to know what steps are being taken to make plain the significance of these important sites. And even at places such as Stonehenge, there is no reason why investigations should not continue throughout the day (and even night). But an accommodation between the professionals and the public would be most easily arranged if some of the modern structures on the site, the work of the department and not the original builders of the monument, were given over to a small museum that would describe what is known of Stonehenge and what is being done to deepen this understanding. As things are, the most evocative monument in Britain could become just a picnic place on one of the ancient routes across Salisbury Plain. That is a shabby fate for the first of all publicly supported research establishments. 